\title{
THE STRUCTURE AND COMPOSITION OF THE LEGISLATURE IN NON-PARLIAMENTARY DRAFT CONSTITUTIONS OF THE REPUBLIC OF POLAND ANNOUNCED IN THE YEARS 1997-2017
}

\author{
Krystyna Leszczyńska \\ Maria Curie-Skłodowska University in Lublin \\ Faculty of Political Science, Department of Journalism \\ e-mail: kles@hektor.umcs.lublin.pl
}

\begin{abstract}
The coming in force of the provisions of the Constitution of the Republic of Poland of 2 April 1997 undoubtedly affected the silencing of the discourse maintained since $1990^{1}$ [Dokumenty programowe...] on the need for the reform of the parliament, including, first of all, its structure (one or two chambers?) and limiting the number of parliamentarians as a guarantee factor - according to the authors of these demands - for improvement of its operation or savings in public finances. However, disputes over the above-mentioned issues, calculated first of all for short-term political effects, were still going on, albeit with varying intensity and distribution of accents. The result of the discourse were various concepts included in party programs, election programs and constitutional projects. Eleven draft constitutions published in the years 1997-2017, but never brought to parliament, were presented by political parties and politicians several months before parliamentary and presidential elections in 2005 and 2015 and before presidential elections in 2010 and also one year before parliamentary elections in 2011. Three draft constitutions were presented on the May $3^{\text {rd }}$ Constitution Day.
\end{abstract}

Keywords: parliament, the Sejm of the Republic of Poland, the Senate of the Republic of Poland, draft constitutions, the structure of the parliament, the size of the parliament

In the years 1997-2017, i.e. in the period of twenty years of the validity of the Constitution of April 2, 1997, which came in force on October 17, 1997, the postulates of changing: 1) the structure of the parliament, 2) modifying the

1 In October 1990, the Polish Socialist Party (PPS) announced - referring to its pre-war program, that the second chamber of parliament was unnecessary. 
composition of the Senate, 3) limiting the number of parliamentarians, were all repeatedly reported. The above proposals were also expressed in extra-parliamentary constitutional projects, i.e. not formally submitted to parliament in accordance with Article 235 section 1 of the Constitution of April 2, 1997. They were presented in "waves" in the years 2004-2005, 2009-2010, and then in 2013 and 2015 [Chruściak 2015: 214-222; Kuciński 2015: 10-26; Kuciński 2013: 132-140]. In the years 2004-2005, the following political parties submitted their draft constitutions: Samoobrona RP ${ }^{2}$ [Projekt Konstytucja ...], Law and Justice (PiS) ${ }^{3}$ [Projekt Konstytucja...] and the League of Polish Families (LPR) ${ }^{4}$ [Projekt Konstytucji...]. In addition, in 2005, an expert team under the leadership of Jan Rokita announced the concept of amending the Constitution of the Republic of Poland under the name "constitutional law" [Państwo dla ...], although an act with this name does not appear in the Constitution of April 2, 1997. In the years 2009-2010, draft constitutions were presented by the Ombudsman (three projects ${ }^{5}$ ) who was de facto recommended for this position by PiS deputies [Leszczyńska 2015: 364], and PiS [Konstytucja Rzeczypospolitej...]. It should be pointed out that at that time, i.e. in 2010, Jarosław Kaczyński's party did not submit a new proposal, only a modified version of the 2005 project. In 2013, constitutional projects were submitted by: Solidarna Polska party (SP) ${ }^{6}$ [Nowa Konstytucja...] and in 2015, by politicians: Janusz Palikot ${ }^{7}$ [Janusz Palikot...] and Janusz Korwin-Mikke ${ }^{8}$.

2 The Samoobrona Rzeczypospolitej Polskiej (Samoobrona RP) political party was active between 1992 and 2000 under the name of Przymierze Samoobrona. In 2000, the Przymierze Samoobrona changed its name to Samobrona Rzeczypospolitej Polskiej. In the elections of 2001 and 2005 Samoobrona RP entered the parliament. The most important period of its functioning came between May 2006 and August 2007, when together with PiS and LPR it formed the ruling coalition.

3 The Prawo $i$ Sprawiedliwość (PiS) [Law and Justice] was formed in 2001, and ever since the September 2001 elections it was represented in the parliament. In the result of the 2015 elections the party gained over half of MP seats, which make it possible for it to rule independently. Since first entering the parliament the PiS created governments in the years of 2005-2007 and from 2015 onwards.

4 The Liga Polskich Rodzin (LPR) [League of Polish Families] political party was formed in 2001, its immediate predecessor was the Liga Rodzin [League of Families]. In the 2001 and 2005 elections, LPR entered the parliament. The most important period of its functioning came between May 2006 and August 2007, when together with PiS and Samoobrona RP it formed the ruling coalition.

5 Konstytucja Rzeczypospolitej Polskiej (projekt pierwszy); Konstytucja Rzeczypospolitej Polskiej (projekt drugi); Konstytucja Rzeczypospolitej Polskiej (projekt trzeci).

6 The Solidarna Polska (SP) political party was formed in 2012. The group was formed after the division in PiS after its loss in the 2011 parliamentary elections. The politicians of this party elected to the European Parliament and during the 2014 local elections did run in cooperation with PiS. During the 2015 parliamentary elections most of them ran from PiS lists. Since 2015, SP party is represented in the government.

7 Janusz Palikot - MP of the $5^{\text {th }}, 6^{\text {th }}$ and $7^{\text {th }}$ term of the Sejm. Leader of the Ruch Palikota party (June, 2011- Ocrober, 2013) later renamed Twój Ruch (in October, 2013). He ran for president in the 2015 presidential elections. In 2017, Palikot declared that he ceases political activities.

8 Janusz Korwin-Mikke - MP of the $1^{\text {st }}$ term of the Sejm, and $8^{\text {th }}$ term of the European Parliament. Presidential candidate in the 1995, 2000, 2005, 2010, 2015 elections. Founder and leader 
It should be pointed out that the last three of these projects were announced on May 3, that is the anniversary of the adoption of the first Polish Constitution.

The objective of the present article is to demonstrate the diversity and dynamics of concepts regarding the structure and composition of the parliament contained in the draft constitution of the Republic of Poland from 1997-2017, which: 1) were documents containing program proposals of specific political parties or politicians; 2) were not brought to parliament, and then attempt to explain the actual intentions of their authors in this regard. The method of analysis of the concept of the structure and composition of the parliament presented by political parties and politicians in non-parliamentary constitutional projects and the descriptive method were used, and also the explanatory method.

\section{STRUCTURE AND COMPOSITION OF THE LEGISLATURE IN NON- PARLIAMENTARY DRAFT CONSTITUTIONS FROM THE YEARS 2004-2005}

Among the announcements of a political shock that was to be made after the parliamentary and presidential elections in $2005^{\circ}$, the main plan was attributed to Prof. Paweł Śpiewak's slogan "Fourth Republic" 10 [Śpiewak 2003: A8], which was, de facto, first coined by Rafał Matyja [Obóz IV Rzeczypospolitej..., 1998]. Roman Giertych's party developed the draft Constitution of the Fourth Republic. In the electoral program of Jarosław Kaczyński's party, entitled IV Rzeczpospolita. Sprawiedliwość dla Wszystkich, it was stated that "the political expression of PiS's strive for the reconstruction of Polish life is emphasized by the transition from the Third to Fourth Republic, stressed in our draft constitution" [Prawo i Sprawiedliwość... . Due to the fact that the above-mentioned draft constitutions were prepared with the intention of using them in the campaign before the parliamentary and presidential

of several different political parties: Unia Polityki Realnej (1990-1997, 1999-2002), Wolność i Praworzadność (2009-2011), Kongres Nowej Prawicy (2011-2015) and Wolność (since 2015).

9 The deep crisis of trust towards the leftist government (2001-2005) made the opposition parties of the $4^{\text {th }}$ term of the Sejm (mainly PO and PiS) face a real chance for taking power in Poland. After almost four years of rule of the social democrats the electoral preferences began to switch their allocations. The sympathy of voters shifted to the "right side". Without any doubt, the main reason for the downfall of the ruling party were the corruption scandals, which were made public by the mass-media, and concerned the politicians of the Sojusz Lewicy Demokratycznej (SLD) [Democratic Left Alliance]. The circumstances in which Lew Rywin, a movie producer, tried to persuade the editor in chief of "Gazeta Wyborcza" Adam Michnik to pay a bribe in return for favourable regulations in the radio and TV-broadcasting act were investigated by a specially appointed commission. The key question of the 2005 electoral campaign was, which party - PiS or $\mathrm{PO}$ - would gather more trust of the voting citizens?

10 "There are many indications that the Third Polish Republic has exhausted its self-healing abilities. It's time to start thinking about the Fourth Republic" [Pol. "Wiele wskazuje na to, że III Rzeczpospolita wyczerpała swoje możliwości samonaprawy. Czas zacząć myśleć o IV Rzeczypospolitej”]. 
elections in autumn 2005, the solutions presented in them were of secondary nature, in the face of the tendency to obtain the best political effect [Chruściak 2009: 132]. LPR and PiS proposed that the legislative authority should be run by a bicameral parliament composed of a 360-member Sejm and Senate. The elections to the Sejm were to be universal, equal and direct and in a secret ballot. The LPR project predicted that the Senate would count 100 members. However, only half of them were to obtain seats in general elections. The other 50 senators were to be chosen by: Poles living abroad (in districts including the number of entitled persons); voivodeship parliaments; senates of universities, namely Warsaw University, Wrocław University, Adam Mickiewicz University in Poznań, Nicolaus Copernicus University in Toruń, Warmia and Mazury University, Szczecin University, Łódź University, Białystok University, Stefan Cardinal Wyszyński University, Silesian University and the Catholic University of Lublin. Considering the rather significant and extremely vague diversity (including a guaranteed place in the Senate for a representative of the Catholic University of Lublin, and not, for example, of Maria Curie-Skłodowska University) in the way of obtaining a senatorial mandate, made this idea quite a controversial concept. In 2005, Kaczyński's party announced that the second chamber would count 30 senators elected by universal suffrage in single-member constituencies. It so happened that PiS's idea, apart from its legitimacy, was not just an isolated case. In the first quarter of that year in Slovakia, a debate was held on the change of the parliament's structure. The effect of the inaugurated discussion at that time was the proposal by the People's Party - Movement for Democratic Slovakia to create a Senate also consisting of 30 members [Pytlik 2013: 74]. In addition, the PiS Senate - modelled after the Constitution of the Republic of Italy, stipulating that by law, the former Presidents of the Republic are lifetime Senators, if, of course, they do not resign ${ }^{11}$ [Staśkiewicz 2011: 854] - the Presidents of the Republic of Poland would enter the office after completing their term of office and taking the oath. In LPR's proposal - in the scope of active and passive electoral law to the Senate - the provisions of the Constitution of April 2, 1997 were repeated. In PiS's draft constitution, acceptance was expressed regarding the age of active suffrage that each Polish citizen aged 18 was entitled to. Passive suffrage in the Senate elections were not only increased to 35 years of age, but also narrowed due to the nomination of candidates for at least 5 years of public office of choice or holding a managerial position in the state.

Samoobrona RP expressed its intention to entrust the legislative power to a unicameral parliament. Elections to the Sejm composed of 460 deputies were to be universal, equal and direct and held in a secret ballot. It was determined that at least $50 \%$ of deputies to the Sejm would be elected in single-member constituencies.

${ }^{11}$ Please refer to Article 59 of the Constitution of the Italian Republic of December 27, 1947, with the last amendment of October 2, 2007. 
The passive suffrage would be granted to Polish citizens who would be 21 years old on the date of election. "Keeping our word to our voters", said Andrzej Lepper,

we have developed a concrete and socially-friendly Socioeconomic Program and a new draft Constitution of the Republic of Poland. They are the expression of the unchanging determination of Samoobrona RP in striving to improve the quality of our lives and to restore the elementary principles of the rule of law and justice [Lepper, Drodzy...].

In turn, the aforesaid expert team under the guidance of Rokita put forward a proposal to abolish the Senate, limit the size of the Sejm, and elect deputies in the majority voting in single-mandate constituencies by amending the Constitution of the Republic of Poland by what they called - as was already mentioned "constitutional law". Due to the fact that the politician managing the works of the above-mentioned expert team was at that time one of the leading activists of Civic Platform (PO), mentioned by it as a candidate for the head of government [Rokita 2013: 228-229], it should be assumed that the project expressed the position of the Platform. This thesis was also confirmed by Rokita, who announced that after being "anointed" by Donald Tusk as the pretender to the position of prime minister, the plans and intentions declared by him were automatically becoming the party's plans and intentions. "So, I justified the need for reforms, I argued that the need to enrich democracy is a trend that covers the entire Western world, I created a concept of changing the constitution and a special law on the repair of public life" [Chruściak 2009: 131-132].

\section{THE STRUCTURE AND COMPOSITION OF THE LEGISLATURE IN NON- PARLIAMENTARY DRAFT CONSTITUTIONS FROM THE YEARS 2009-2010}

The draft constitution presented by the Ombudsman constituted - as he described it - "three visions of the system of government", i.e. 1) a rationalized parliamentary-cabinet system, 2) parliamentary-cabinet system with a strong government position and weakened role of a unicameral parliament, 3) presidential system. The first of these assumed the existence of a bicameral parliament composed of a 300-person Sejm and a 50-member Senate. Both deputies and senators were to be elected by universal, equal, direct and secret ballot. The passive electoral right to the Sejm was to be vested in Polish citizens who were 25 or older on the election day. Polish citizens who were 30 or older on the election date, could run for the Senate. The second and third project announced by Dr. Janusz Kochanowski predicted the existence of a unicameral Sejm in the shape proposed in the first draft. In the draft constitution of 2010, the group of Kaczyński reiterated the concept of a bicameral parliament. The Sejm was to consist of 360 deputies elected by universal, equal and direct elections in a secret ballot. The Senate was to be composed of 50 elected senators. It was assumed that persons who held 
the office of the head of state in the past would become senators if they chose to make an appropriate oath at a strictly specified time. Undoubtedly, PiS came to the conclusion that a body of just 30 members would not be able to effectively fulfill the tasks of a parliamentary chamber, being, at the same time, a representative body. Elections to the Senate were to be managed by the President of the Republic of Poland simultaneously with direct elections to local self-government bodies [Konstytucja Rzeczypospolitej...; Chruściak 2009: 149].

It should be added that on February 19, 2010 - i.e. one month after PiS announced a new draft constitution - PO submitted to the Sejm of the Republic of Poland a bill amending the Constitution of the Republic of Poland [Sejm Paper No. 2989...]. The amendment of the Constitution submitted to the Marshal of the Polish Sejm aimed at reducing the number of deputies and senators, and allowing active role in public life to former Presidents of the Republic of Poland elected by universal suffrage (institution of lifetime senators), if, of course, they did not renounce this right. On October 22, 2010, the draft of amendment to the Constitution of the Republic of Poland as included in Journal No. 2989 was rejected (primarily by the votes of PiS and PSL) [Vote No. 19; Chruściak 2013: 162-187].

\section{THE STRUCTURE AND COMPOSITION OF THE LEGISLATURE IN NON- PARLIAMENTARY DRAFT CONSTITUTIONS FROM 2013 AND 2015}

In 2013, the Solidarna Polska party (SP) formed by former PiS activists headed by Zbigniew Ziobro announced the proposed changes to the current Constitution of 1997. This document specifies that the legislative powers shall be vested in the Sejm alone, which was limited to 230 deputies, that is half of the current panel of the first chamber. The elections would be five-adjective: free, universal, equal, direct and were to take place in a secret ballot. A passive electoral right would apply to citizens who were 21 or older. "I am ready to retreat to the second, third plan. I am ready to run for the Senate", declared Ziobro several months later [Statement of Zbigniew Ziobro...].

Exactly two years later, Janusz Palikot presented the postulate of a unicameral parliament. The leader of Twój Ruch and, at the same time, the candidate for the office of President of the Republic of Poland pointed out, during the press conference organized in spring 2015 before entering the Senate under the slogan "I will make order with them", that the postulate of a unicameral parliament was always present in the program of the party he is managing. "The Senate is one of the greatest absurdities of the Polish political system and Polish politics. This is a completely unnecessary, facade and barren institution", argued Palikot. Legislative power should be vested in the Sejm alone, which was to be elected by universal, equal, direct, proportional elections and secret ballot. The number of deputies elected in a given term should reflect the electoral turnout and be determined as follows: for every $0.25 \%$ of those entitled to vote who did not take 
part in it, one seat from the total number of 460 is deducted. A passive electoral right to the Sejm was to be granted to Polish citizens with the right to vote, who were 25 or older on election date. In the New Constitution document prepared by Twój Ruch in 2015, one can see a certain inconsistency on the part of the project promoter. Although Chapter IV only recognized the unicameral Sejm as a legislative authority in the Republic of Poland, in nine articles (Articles 58, 98, 115, 124, $180,181,187,188,213)$ a reference to the Senate was included, Senate Chancellery or senators. For example: "The mode of providing information referred to in sections 1 and 2 -information on the activities of public authorities and persons in offices - are defined by laws, and in relation to the Sejm and the Senate, their regulations" (Article 58, section 4). Certainly, this unintentional action was the result of the inattention or hurry.

On 3 May 2015, Janusz Korwin-Mikke announced a draft constitution containing an extremely utopian vision of depriving the Sejm of legislative powers and handing them over to the eleven-member Council of State, composed of persons nominated by "rectors of the most important universities" and appointed by the president (4), elected by Senate (4), elected by the Sejm (3) and operating under the control of the Senate and the President. The most important body constituting the acts of law was to be the Senate consisting of the representatives elected "two from each Land" for a six-year term in intermediate elections by electors who were at least 29 years old (with the election of one senator every three years). The constitution projects from 2013 and 2015 were announced on the May $3^{\text {rd }}$ Constitution Day. The common feature of proposals by SP and Palikot was the concept of a unicameral parliament.

\section{CONCLUSIONS}

In the years 1997-2017, i.e. during the twenty years of validity of the Constitution of April 2, 1997, the need for fundamental changes in the structure of legislative power and the number of parliamentarians was usually declared a dozen or so months before the parliamentary and presidential elections of 2005 and 2015 and before the presidential election 2010 and parliamentary ones in 2011. More than half, and specifically six out of eleven non-parliamentary constitutional projects submitted at that time, provided for a unicameral structure of the parliament. In four constitutional projects, the Sejm and Senate were specified as the legislative authorities. One draft constitution contained a proposal to deprive the Sejm of legislative powers in favor of the organ called the Council of State and the establishment of the Senate as the most important legislative body.

In seven constitutional projects, it was suggested that the number of members of the Sejm should be limited to 360,300 or 230 . It should be emphasized that the expert team under the direction of Rokita did not specify the reduced number of MPs, whereas Palikot postulated that this number should reflect the voter turnout. 
It was assumed that the number of Senate members would be maintained at the level of 100 seats or limited to 50 or even 30 . The following are the premises for the fact that the postulates of changing the structure of the parliament or reducing the number of parliamentarians included in non-parliamentary constitutional projects were only political declarations: 1) they were never brought to the parliament, they were in the form of documents containing program proposals of specific political parties or politicians; 2) the date of their announcement usually took place a few or several months before the elections to the parliament or the office of the President of the Republic of Poland; 3) there is a lack of coherence between the state postulated in them and the actual political actions. For example: a) representatives of four of the five political parties in favour of the abolition of the Senate were running for this very house of parliament; b) although the members of Palikot's party did not run for the Senate, the draft constitution prepared by their leader, which recognized only the unicameral Sejm as a legislative authority in the Republic of Poland, contained certain references to the Senate, Senate Chancellery or senators.

Tytul: Struktura i skład legislatywy w pozaparlamentarnych projektach Konstytucji RP ogłoszonych w latach 1997-2017

Streszczenie: Wejście w życie postanowień Konstytucji RP z 2 kwietnia 1997 r. wpłynęło niewątpliwie na wyciszenie dyskursu (prowadzonego od $1990 \mathrm{r} .{ }^{12}$ ) na temat potrzeby reformy parlamentu, w tym przede wszystkich jego struktury (jedna czy dwie izby?) oraz ograniczenia liczby parlamentarzystów jako czynnika gwarantującego - w założeniu autorów tych postulatów - usprawnienie prowadzonych przez niego prac lub zwiększenie oszczędności w finansach publicznych. Jednak spory wokół wyżej wymienionych kwestii, obliczone przede wszystkim na doraźne efekty polityczne, toczyły się nadal, choć z różnym natężeniem i rozłożeniem akcentów. Efektem prowadzonego dyskursu były różnorodne koncepcje zawarte w programach partyjnych, programach wyborczych oraz projektach konstytucji. Jedenaście projektów konstytucji ogłoszonych w latach 1997-2017, ale nigdy niewniesionych do parlamentu, przedstawiły zarówno partie polityczne, jak i politycy na kilkanaście lub kilka miesięcy przed wyborami parlamentarnymi i prezydenckimi 2005 i 2015 r. oraz przed wyborami prezydenckimi w 2010 r. i zarazem na rok przed wyborami parlamentarnymi 2011. Trzy projekty dokumentu przedstawiono w święto Konstytucji 3 maja.

Słowa kluczowe: parlament, Sejm RP, Senat RP, projekty konstytucji, struktura parlamentu, liczebność parlamentu

${ }^{12}$ W październiku 1990 r. Polska Partia Socjalistyczna (PPS) ogłosiła - nawiązując do przedwojennej linii programowej, że druga izba parlamentu to instytucja zbędna. Zob. Dokumenty Programowe Polskiej Partii Socjalistycznej uchwalone przez XXV Kongres PPS, Warszawa 27-29.10.1990, s. 12, Polska Partia Socjalistyczna 1990-1994, s. 92. 


\section{REFERENCES}

1. Chruściak, R., 2009, Prace konstytucyjne w latach 1997-2007, Wydawnictwo Sejmowe, Warszawa.

2. Chruściak, R., 2013, Prace konstytucyjne w latach 2008-2011, Wydawnictwo Sejmowe, Warszawa.

3. Chruściak, R., 2015, Propozycje zmian konstytucyjnych w latach 1997-2012, [in:] A. MaterskaSosnowska, T. Słomka (red.), Konstytucje polskie z 1952 i 1997 roku: tradycja, instytucje, praktyka ustrojowa, Wydawnictwo Elipsa, Warszawa.

4. Dokumenty Programowe Polskiej Partii Socjalistycznej uchwalone przez XXV Kongres PPS, Warszawa 27-29.10.1990 [Archiwum Partii Politycznych, hereinafter referred to as: APP], Polska Partia Socjalistyczna 1990-1994.

5. Janusz Palikot-kandydat na Prezydenta RP. Nowa Konstytucja-tekst jednolity uwzględniajacy propozycje programowe i poprawki zgłoszone przez Twój Ruch, 2015 (access: 05.05.2016).

6. Konstytucja Rzeczypospolitej Polskiej. Projekt Prawa i Sprawiedliwości, Warszawa, styczeń 2010.

7. Konstytucja Rzeczypospolitej Polskiej. Projekt Prawa i Sprawiedliwości, Warszawa, 15 stycznia 2010 r., www.pis.org.pl/ (access:16.03.2013).

8. Konstytucja Republiki Włoskiej z 27 grudnia 1947 r. z ostatnią zmianą z dnia 2 października 2007 r., [in:] W. Staśkiewicz (red.), Konstytucje państw Unii Europejskiej, Wydawnictwo Sejmowe, Warszawa 2011.

9. Korwin-Mikke, J., 2015, Tekst projektu Konstytucji nowego Państwa Polskiego, http://korwin-mikke.pl/blog/wpis/tekst_projektu_konstytucji_nowego_państwa_polskiego (access: 05.04.2017).

10. Kuciński, J., 2015, Koncepcje przekształceń ustrojowych w pozaparlamentarnych projektach konstytucji RP ogloszonych w latach 2004-2013, Wydawnictwo Społecznej Akademii Nauk, Warszawa-Lódź.

11. Kuciński, J., 2013, Solidarnej Polski koncepcja reformy ustroju konstytucyjnego Rzeczypospolitej Polskiej, „Przegląd Prawa Konstytucyjnego”, No. 4 (16).

12. Lepper, A., Drodzy Rodacy - życzenia na Boże Narodzenie oraz Nowy Rok 2004 [APP] Samoobrona RP 2002-2005.

13. Leszczyńska, K., 2015, Senat Rzeczypospolitej Polskiej w latach 1989-2011, Wydawnictwo UMCS, Lublin.

14. Nowa Konstytucja Rzeczypospolitej Polskiej, Warszawa, 3 maja 2013 r., www.solidarnapolska. org.pl (access: 10.05.2018).

15. Obóz IV Rzeczypospolitej, "Debata" of 1998, IV Rzeczpospolita - Wiadomości - WP.PL, http:// wiadomosci.wp.pl/kat,43834,title,IV-Rzeczpospolita,wid,8118743, wiadomosc.html (access: 30.12.2005).

16. Państwo dla Obywateli. Plan rządzenia 2005-2009, Instytut Państwa i Administracji, Warszawa, grudzień 2005.

17. Prawo i Sprawiedliwość. Program 2005: IV Rzeczypospolita. Sprawiedliwość dla Wszystkich, www.pis.org.pl (access: 14.02.2013).

18. Projekt Konstytucja Rzeczypospolitej Polskiej przygotowany przez Samoobronę 19 grudnia 2004 r., www.samoobrona.org.pl (access: 25.01.2013).

19. Projekt Konstytucja Rzeczypospolitej Polskiej przygotowany przez Prawo i Sprawiedliwość w 2005 r., www.pis.org.pl (access: 25.01.2013).

20. Projekt Konstytucji Czwartej Rzeczypospolitej przygotowany przez Ligę Polskich Rodzin, www. lpr.org.pl (access: date unknown).

21. Projekt Konstytucja Rzeczypospolitej Polskiej (projekt pierwszy) przygotowany przez Rzecznika Praw Obywatelskich, https://www.salon24.pl/u/blog/brpo/121307 (access: 15.09.2009). 
22. Projekt Konstytucja Rzeczypospolitej Polskiej (projekt drugi) przygotowany przez Rzecznika Praw Obywatelskich, https://www.salon24.pl/u/blog/brpo/121307 (access: 15.09.2009).

23. Projekt Konstytucja Rzeczypospolitej Polskiej (projekt trzeci) przygotowany przez Rzecznika Praw Obywatelskich, https://www.salon24.pl/u/blog/brpo/121307 (access: 15.09.2009).

24. Rokita, J.M., 2013, Anatomia przypadku. Rozmowa z Robertem Krasowskim, Czerwone i Czarne, Warszawa, pp. 228-229.

25. Sejm Paper No. 2989, the Sejm of $6^{\text {th }}$ term.

26. Statement of Zbigniew Ziobro in the Jeden na jeden show broadcasted by TVN on 8 July 2014.

27. Śpiewak P., 2003, Koniec złudzeń, „Rzeczpospolita”, 23/01/2003, No. 19.

28. Vote No. 19 held during the $76^{\text {th }}$ meeting of Sejm of the Republic of Poland on 22 October 2010 at 9:23. 